KS. GRZEGORZ BUJAK* - LUBLIN

\title{
KANCELARIA PARAFIALNA W ZABORZE AUSTRIACKIM I JEJ DOKUMENTACJA NA PRZEŁOMIE XIX I XX WIEKU
}

\begin{abstract}
Streszczenie
Kościół katolicki spełniał ważne zadania w strukturze administracyjnej monarchii habsburskiej. Były one realizowane w oparciu o sieć parafialną i przepisy państwowe oraz kościelne. Dla ich realizacji niezbędna była sprawnie działająca kancelaria parafialna, która w odpowiednich formach rejestrowała zróżnicowane informacje dotyczące życia wiernych i działalności duszpasterskiej. $\mathrm{W}$ artykule zostały przedstawione zasady organizacji kancelarii, registratury i archiwum w parafiach katolickich na terenie zaboru austriackiego w szczytowym okresie ich rozwoju na przełomie XIX w XX wieku. Zostały omówione cele i sposoby prowadzenia ksiąg metrykalnych i innych form dokumentacji parafialnej oraz zasady korespondencji urzędowej. Podstawą opracowania był podręcznik prowadzenia kancelarii parafialnej dla duchowieństwa, autorstwa ks. Alojzego Jougana, profesora uniwersytetu we Lwowie z 1912 r., w którym omówione zostały formalno-prawne i praktyczno-duszpasterskie zasady prowadzenia kancelarii parafialnej.
\end{abstract}

Słowa kluczowe: kancelaria parafialna; archiwum parafialne; księgi parafialne; Kościół w zaborze austriackim

\section{Wstęp}

W drugiej połowie XVIII wieku kościelne struktury administracyjne zostały włączone w proces przebudowy państwa Habsburgów w duchu ideałów oświeconego absolutyzmu. W jego wyniku Kościół w monarchii stał się jedną z instytucji państwa autokratycznego. W tej sytuacji szczególna rola przypadła parafii, która będąc lokalnym centrum życia religijnego, stała się istotnym elementem struktury

* Ks. Grzegorz Bujak - dr hab. historii, prof. KUL, Instytut Historii, Katolicki Uniwersytet Lubelski Jana Pawła II

e-mail: grzegorz.bujak@kul.pl

https://orcid.org/0000-0003-2298-2757 
administracyjnej państwa i nadzoru nad poddanymi. $Z$ tego względu wzrosło znaczenie administracyjnych i formalno-prawnych aspektów działalności duchowieństwa parafialnego. Skutkowało to rozwojem i profesjonalizacją kancelarii parafialnych, które istniejąc od wieków, musiały przejść gruntowne przemiany, aby sprostać nowym zadaniom, jakie wypływały z usytuowania struktur kościelnych w panstwie oświeconego absolutyzmu ${ }^{1}$.

Kancelaria parafialna była miejscem, w którym zbiegały się dwa systemy administracyjne - kościelny i państwowy, obsługiwała właściwe dla obu obszarów zadania, podlegając $\mathrm{w}$ ich realizacji zarówno przepisom kościelnym, jak i państwowym. Wzajemne relacje w tym zakresie były zmienne w czasie i zależały od religijnych oraz społeczno-politycznych przemian zachodzących w XIX wieku. W wyniku tych procesów na przełomie XIX i XX wieku kancelaria parafialna w państwie Habsburgów osiągnęła wysoki poziom organizacji i profesjonalizmu dla realizacji biurowej obsługi parafii w zakresie zadań nakładanych tak przez władze kościelne, jak i państwowe.

Ziemie polskie włączone w wyniku rozbiorów do państwa austriackiego stały się jego integralną częścią i podlegały procesom zachodzącym w całej monarchii habsburskiej. Dotyczyło to także kwestii organizacji życia religijnego i usytuowania struktur kościelnych $\mathrm{w}$ państwie. Treścią niniejszego artykułu jest omówienie organizacji kancelarii parafialnej w Galicji i rodzajów dokumentacji wytwarzanej w wyniku jej pracy w okresie szczytowego rozwoju, na przełomie XIX i XX wieku.

Badania dotyczące kancelarii kościelnych na ziemiach polskich mają obszerną bibliografię. Syntetyczne ujęcia dziejów kancelarii parafialnych zawierają prace Roberta Kufla i Tomasza Moskala ${ }^{2}$. Z kolei Piotr Rachwał i Janina Gawrysiakowa, w publikacjach opartych na analizie ksiąg metrykalnych, ustalenia interesujących nas kwestii poruszają w kontekście badań nad ruchem naturalnym ludności ${ }^{3}$. Z badań nad kancelariami kościelnymi w zaborze austriackim na uwagę zasługują artykuły Bolesława Kumora omawiające przepisy austriackie dotyczące ksiąg metrykalnych ${ }^{4}$.

${ }^{1}$ J. Krętosz, Józefiński proces budowy Kościoła państwowego na terenie monarchii habsburskiej w okresie rząów cesarza Józefa II (1780-1790), „Śląskie Studia Historyczno-Teologiczne”, 29 (1996) s. 41-44.

${ }^{2}$ R. Kufel, Kancelaria, registratura i archiwum parafialne na ziemiach polskich od XII do początków XXI wieku, Zielona Góra 2011; T. Moskal, Historia ksiag metrykalnych kościoła katolickiego na ziemiach polskich, „Archiwariusz. Biuletyn Archiwum Archidiecezjalnego w Poznaniu”, (2005) nr 1, s. 55-82.

${ }^{3}$ P. Rachwał, Ruch naturalny ludności rzymskokatolickiej $w$ Lubelskiem w świetle rejestracji metrykalnej z lat 1582-1900, Lublin 2019; tenże, Księgi metrykalne z czasów zaboru austriackiego $w$ archiwach parafialnych $w$ Lubelskiem - regulacje prawne, stan zachowania, „,Rocznik Lubelskiego Towarzystwa Genealogicznego”, 6 (2015) s. 306-325; J. Gawrysiakowa, Grupy wyznaniowe ludności w Lubelskiem w XIX wieku, Lublin 1992.

${ }^{4}$ B. Kumor, Przepisy państwowe i kościelne dotyczace metryk kościelnych w zaborze austriackim (1800-1914), „Przeszłość Demograficzna Polski”, 7 (1975) s. 93-107; tenże, Metryki parafialne w archiwach diecezjalnych, „Kwartalnik Historii Kultury Materialnej”, (1966) nr 14, z. 1, s. 65-75. 
Podstawą źródłową niniejszego artykułu jest wydany we Lwowie w 1912 r., przeznaczony dla duchowieństwa, podręcznik profesora tamtejszego uniwersytetu ks. Alojzego Jougana ${ }^{5}$. Miał on charakter publikacji o charakterze duszpasterskim z silnym w Austrii rysem formalno-prawnym, w którym autor najwięcej uwagi poświęcił praktycznym aspektom pracy kancelaryjnej. Na początku publikacji obszernie omówił przepisy kościelne i państwowe dotyczące prowadzenia kancelarii oraz poszczególnych rodzajów dokumentacji parafialnej. W dalszej treści podręcznika odwołania do konkretnych przepisów występują rzadko. Przedstawione w książce zasady dotyczące organizacji kancelarii, a przede wszystkim typologia dokumentacji parafialnej, są niezwykle cenne, gdyż zostały omówione z uwzględnieniem kazusów prawnych i wskazówek praktycznych właściwych dla epoki. Podręcznik ks. A. Jougana ma dla problematyki niniejszego artykułu szczególne znaczenie także $\mathrm{z}$ tego powodu, że przedstawia formalno-prawne i praktyczno-duszpasterskie aspekty prowadzenia kancelarii i dokumentacji parafialnej w szczytowym momencie jej organizacji, tj. na przełomie XIX i XX wieku.

Struktura artykułu odzwierciedla założone cele badawcze, obejmujące jedynie wybrane aspekty obszernej problematyki kancelaryjnej, przedstawione w liczącym tysiąc stron podręczniku ks. A. Jougana. Najpierw omówione zostaną zasady organizacji kancelarii parafialnej oraz powiązanych z nią registratury $i$ archiwum, następnie kwestie związane z prowadzeniem ksiąg metrykalnych $i$ innej dokumentacji parafialnej, a na zakończenie specyfika parafialnej korespondencji urzędowej.

\section{Kancelaria, registratura i archiwum parafialne}

Organizacja kancelarii parafialnej zależała od wielu czynników. Jednak mimo znacznego zróżnicowania wynikającego z wielkości parafii, liczby wiernych i duchownych parafie posiadały taki sam zakres formalnych obowiązków i uprawnień, wypełniając w większości identyczne zadania stawiane przed nimi przez władze kościelne i świeckie. Parafie w Galicji w większości miały charakter wiejski, a co za tym idzie - podobny profil społeczny wiernych. Przede wszystkim do duszpasterzy takiej typowej i przeciętnej parafii o charakterze wiejskim kierował ks. A. Jougan swoje uwagi dotyczące praktycznych warunków organizacji kancelarii.

Na początku zwrócił uwagę na fakt, że kancelaria parafialna była organizowana na terenie plebanii, a najczęściej zajmowała ,jeden z pokoi na plebanii”. Nie była więc typowym pomieszczeniem biurowym, a stosowne warunki dla pracy biurowej, w tym dla kontaktów z petentami, należało dopiero stworzyć, odpowiednio adaptując takie pomieszczenie. Następnie ks. A. Jougan wymienił typowe i niezbędne wyposażenie kancelarii:

Najważniejszym w niej urządzeniem jest stół (biuro) do pisania, na nim krzyż

z dwiema świecami (dla odebrania ewentualnej przysięgi manifestacyjnej)

${ }^{5}$ A. Jougan, Kancelaria parafialna czyli zbiór przepisów kościelnych i państwowych dla urzędów parafialnych, ze szczególnym uwzględnieniem ksiąg metrykalnych, Lwów 1912. 
a nadto półki na księgi i akta łącznie z biurem w formie nastawy z przedziałami, lub też szafa oddzielnie od biura (obok niego) umieszczona ${ }^{6}$.

Jak z tego wynika, pod pojęciem ,,biuro” autor rozumiał miejsce do pracy o charakterze kancelaryjnym, czyli typowe dla kancelarii austriackiej biurko z nastawą, z piętrowo umieszczonymi przegródkami na akta. Zamiast w nastawie akta mogły być gromadzone w osobnej szafie, w której - poza bieżącą dokumentacją znajdowały się inne materiały niezbędne dla prawidłowego funkcjonowania kancelarii:

W tej szafie należy przechowywać kościelne i państwowe rozporządzenia, kurendy konsystorskie lub urzędowe czasopisma diecezjalne, księgi ustawy cywilne (kodeksy), dzienniki ustaw państwowych i krajowych, podręczniki dla prawa kanonicznego i małżeńskiego, podręczniki kancelaryjne, formularze do podań, schematyzmy, kalendarz, księgi adresowe, skorowidz miejscowości w Galicji celem wyszukania poczty lub powiatu, gdy wypadnie pisać o jakąś metrykę lub dla uwiadomienia proboszcza miejsca urodzenia o ślubie lub śmierci danej osoby ${ }^{7}$.

Ze względu na swoje znaczenie, specjalnie wydzielone miejsce w nastawie biurowej zajmowały akta dotyczące spraw małżeńskich, które „wymagają zwykle osobnego fachu (przedziału)". Akta dotyczące aktualnie załatwianych w kancelarii spraw winny być ,posortowane wedle treści i złożone w teki z odpowiednim napisem (np. protokoły legitymacyjne, świadectwa metrykalne itp.)". Tak przygotowane należało je układać ,w osobnych przedziałach tej szafy podręcznej lub nasady biurowej"8.

Podstawową pomocą w bieżącej pracy kancelaryjnej był dziennik podawczy, nazywany protokołem czynności (protocollon gestionis). Prowadzono w nim ewidencję całej korespondencji urzędowej oraz wystawianych dokumentów i zaświadczeń. Zasady jego prowadzenia nie odbiegały od typowego dziennika podawczego. Rejestracja każdego pisma obejmowała numer kolejny, datę wpływu lub ekspedycji, nadawcę i streszczenie? .

W nastawie biurowej powinny znajdować się jedynie dokumenty związane z bieżącą pracą urzędu parafialnego. Dokumentację dotyczącą spraw zamkniętych należało gromadzić osobno w registraturze:

przysłane do kancelarii pisma, jak koncepty (bruliony) odesłanych z kancelarii ekspedycji zbiera się w pewnych czasu odstępach z biura kancelaryjnego i prze-

\footnotetext{
${ }^{6}$ Tamże, s. 787.

${ }^{7}$ Tamże, s. 787.

${ }^{8}$ Tamże, s. 787.

${ }^{9}$ „Dla ewidencji wszelakich pism urzędowych, tak otrzymanych, jak wysłanych lub wysłać się mających, powinien w każdej kancelarii parafialnej znajdować się na biurze protokół czynności (protocollon gestionis) albo dziennik (diarium), w którym wedle bieżącej cyfry porządkowej wpisuje się owe pisma, datę ich otrzymania (praes.) lub wysłania (exp.), ich streszczenie krótkie, ich pochodzenie, a względnie przeznaczenie (adresat). Najdogodniejszą formą protokołu czynności byłaby taka, gdzieby po jednej stronie mieściły się wpływy, po drugiej ekspedycje pism urzędowych. Obecnie jednak wszystkie urzędy używają formularzy (tabelarycznych) protokołu czynności - bez dzielenia czynności kancelaryjnych na dwie kategorie". Tamże, s. 787-788.
} 
nosi do tak zwanej registratury czyli do osobnej zamykanej szafy z półkami i przedziałkami (fach) i stosownie do treści wkłada się je do odnośnego fascykułu lub do oddzielnej teki w przedziałki registratury, odpowiednim napisem zaopatrzone i wedle pewnego porządku ugrupowane, aby w potrzebie można je łatwo odnaleźćc ${ }^{10}$.

Akta w registraturze należało układać poziomo, luźno, aby uniknąć zniszczenia dokumentacji. Dlatego poszczególne przedziały na półkach registratury (fachy) powinny być odpowiednio głębokie dla zmieszczenia typowego arkusza papieru: „Szafa tedy na nie przeznaczona powinna być $45 \mathrm{~cm}$ głęboka, a przedziały około $30 \mathrm{~cm}$ wysokie i szerokie". Dla akt gromadzonych w registraturze należało sporządzić osobne pomoce inwentarzowe. Należały do nich indeksy rzeczowe i alfabetyczne repertoria: ,z oznaczeniem treści i osób”. W registraturze obowiązywał rzeczowy porządek składowania akt ${ }^{11}$.

Szafa zawierająca registraturę powinna być odpowiednio zabezpieczona. Nie należało jej umieszczać blisko przewodów kominowych, które często były nieszczelne, a wydobywające się z nich iskry groziły pożarem. Równie niebezpieczna była wilgoć, dlatego nie należało umieszczać szafy przy ścianach zewnętrznych plebanii i zawsze zachowywać odstępy umożliwiające swobodną cyrkulację powietrza. Powinna być ona zamykana na klucz, do którego dostęp mógł mieć tylko proboszcz. Niewłaściwym miejscem jej umieszczania była sień lub korytarz, gdyż korzystające $z$ tych miejsc osoby mogły wejść w posiadanie dokumentów bądź zawartych w nich informacji. Najwłaściwszym miejscem była kancelaria albo przylegający do niej pokój. Ułatwiało to podczas pracy biurowej korzystanie ze zgromadzonych akt i dodatkowo chroniło dokumenty, gdyż sama kancelaria powinna być stale zamknięta na klucz ${ }^{12}$.

Od registratury należało odróżniać archiwum parafialne: „było ono wprawdzie częścią registratury, ale najważniejszą i dlatego wszelkie przepisy i zastrzeżenia, odnoszące się do registratury, w wyższym jeszcze stopniu odnieść należy do archiwum". Stanowiło ono wydzieloną jej część i służyło gromadzeniu najważniejszych dokumentów, głównie ksiąg metrykalnych. Szczegółowy wykaz akt wskazanych do przechowywania w archiwum parafialnym został zamieszczony w okólniku konsystorza lwowskiego z 1896 r. $^{13}$

10 Tamże, s. 789.

${ }^{11}$ A. Jougan wymieniał następujące grupy rzeczowe akt: „Registratura parafialna powinna mieścić przynajmniej następujące oto fascykuły z aktami; 1) budowy, 2) bractwa religijne, 3) fundacje, 4) sprawy hipoteczne, 5) protokoły przedślubne, dyspensy i w ogóle sprawy małżeńskie, 6) legitymacje dzieci nieślubnych, 7) wykazy statystyczne, 8) kolekty, 9) sprawy wikarych, 10) sprawy cmentarne, 11) sprawy patronatu, 12) sprawy metrykalne, 13) sprawy szkolne, 14) sprawy opieki i rad sierocych, 15) sprawy plebańskie, 16) dochody, ciężary i prawa plebanii, 17) wizytacje kanoniczne, 18) rozporządzenia rządowe i 19) konsystorskie, 20) porządek nabożeństwa i zarządzenia liturgiczne, 21) sprawy organistowskie, 22) nawrócenia i apostazje, 23) separacje w sądach cywilnych, 24) umowy o religijne wychowanie dzieci, 25) kurendy i listy pasterskie, 26) polecenia dziekańskie itd.”. Tamże, s. 790-791.

12 Tamże, s. 793.

${ }^{13}$, , (...) nowe, jak stare, wszelkie dokumenty erekcyjne i dotacyjne, bulle, brewe, kroniki, nie mniej inne dla kościoła lub plebanii ważne akta starodawne i dokumenty historyczne, jako to: dy- 
Zarówno władze kościelne, jak i państwowe doceniały wagę właściwej organizacji archiwum parafialnego. Nadzór kościelny polegał na corocznej kontroli dziekańskiej stanu archiwum i jego zawartości. Z kolei namiestnictwo lwowskie wydało zarządzenie, aby w nowych plebaniach wznoszonych z udziałem środków państwowych, uwzględniano odpowiednie miejsce na archiwum: ,aby było ogniotrwałe, sklepione, zaopatrzone w żelazne drzwi i takież okienice" ${ }^{14}$.

\section{Księgi metrykalne}

Najistotniejszą część dokumentacji prowadzonej w kancelarii parafialnej stanowiły księgi metrykalne. Według ks. A. Jougana „,najważniejszym zajęciem tej kancelarii, a zarazem jedną z głównych agend urzędu parafialnego, jest utrzymywanie czyli prowadzenie ksiąg kościelnych, parafialnych czyli metrykalnych". Zgodnie z przepisami zaliczał do nich: księgi ochrzczonych, zaślubionych i zmarłych, podkreślając, że „księgi te są instytucją zarówno kościelną jak i państwową”. Wielokrotnie powtarzał, iż metryki „są własnością Kościoła”, a prowadząc je, Kościół „wyświadcza państwu i społeczeństwu ważną przysługę”15.

Znaczenie ksiąg metrykalnych dla administracji państwa według ks. A. Jougana polegało na tym, że zawierały one informacje ważne ze względu na ,świeckie stosunki prawne". $Z$ tego powodu

wpisy w księgi parafialne służyły od dawna zarazem celom państwowym, a same księgi metrykalne uchodzily za rejestry stanu cywilnego i otrzymały także in foro civili moc dokumentów publicznych, zaś prowadzenie metryk zaliczono do spraw publicznej administracji.

Prowadzenie ksiąg metrykalnych zostało uznane za ,jedną z czynności urzędowych" a duchowni, którzy się tym zajmowali, mieli status „państwowych urzędników stanu cywilnego"16.

To, że księgi metrykalne prowadzone przez proboszczów posiadały status dowodowy przed organami władzy państwowej, miało dla A. Jougana także ważne znaczenie duszpasterskie. Zwracał uwagę, że

w obecnych stosunkach potrzeba parafian odnoszenia się do urzędu parafialnego w sprawach metrykalnych jest częstokroć jedynym łącznikiem ich wzajemnym w dziedzinie duszpasterskiej, nastręczającym dogodną sposobność do zadzierzgnięcia i podtrzymywania nadal obopólnego związku duchowego między kapłanem a ludem ${ }^{17}$.

Na przestrzeni XVIII i XIX wieku władza państwowa wydawała wiele przepisów szczegółowo regulujących prowadzenie ksiąg metrykalnych ${ }^{18}$. Najważniej-

plomy, kontrakty i sprzedaży, dzierżawy, akta i listy fundacyjne, mapy i arkusze gruntowe, inwentarze, umowy zmieniające pewne ciężary (serwituty) na kapitały, wypisy hipoteczne, papiery wartościowe, polisy asekuracyjne, fasje, kwity podatkowe itd.”. Tamże , s. 794-795.

${ }^{14}$ Tamże, s. 795.

${ }^{15}$ Tamże, s. 34.

${ }^{16}$ Tamże, s. 35. Już w okresie rządów Marii Teresy i Józefa II księgi metrykalne uzyskały status dokumentu publicznego, por. Rachwał, Księgi metrykalne z czasów zaboru austriackiego, s. 308.

${ }^{17}$ Jougan, Kancelaria parafialna, s. 36.

${ }^{18}$ Gawrysiakowa, Grupy wyznaniowe ludności w Lubelskiem, s. 33. 
szym, choć nie pierwszym z nich, był patent cesarski z 20 lutego 1784 r., w którym zarządzono, ,aby księgi metrykalne prowadzone były (in folio) w formie tabelarycznej z rubrykami”. Hieronim Wyczawski podkreślał, że to w Austrii najwcześniej wprowadzono zunifikowane formularze ksiąg metrykalnych. Z tych doświadczeń korzystały instytucje kościelne na ziemiach polskich w pozostałych zaborach $^{19}$.

Ks. A. Jougan zwracał uwagę, że dzięki stosowaniu formularzy łatwiej można było uchwycić ewentualne błędy i dotrzeć do potrzebnych informacji: „ta forma jest $\mathrm{z}$ tego względu dogodna, że przy troskliwym przestrzeganiu napisów poszczególnych rubryk w nagłówku można dokonywać wpisów zupełnych i - ile możności - bez błędów". Do patentu z 1784 r. dołączone były wzory formularzy z określeniem zawartości poszczególnych rubryk i zasady ich prowadzenia ${ }^{20}$. Było to o tyle ważne, że proboszcz dokonujący wpisu w metryce ponosił pełną odpowiedzialność za jego treść. O tej odpowiedzialności, przez cały XIX wiek przypominały zarówno władze kościelne, jak i świeckie, m.in. gubernator lwowski w dekrecie z 6 października 1837 r.:

Wpisy do ksiąg metrykalnych uskuteczniać mają duchowni, dopełniający aktu własnoręcznie, bez żadnej zwłoki i z przestrzeganiem przepisów w tej mierze obowiązujących. Proboszczowie są do tych czynności urzędnikami stanu i są odpowiedzialni za każdą wpisaną nieprawdę, czy ona pochodzi z nieczytelnego wpisania, czy z omyłki, czy z dodatkowych zapisów ${ }^{21}$.

Omówienie problematyki dotyczącej prowadzenia księgi ochrzczonych (liber baptisatorum) autor połączył z obszernym wykładem przepisów kościelnych i państwowych, objaśniających znaczenie tego sakramentu na płaszczyźnie religijnej i świeckiej. Wyjaśnił, kto jest uprawniony do jego udzielenia i dokonywania wpisów w księdze metrykalnej. Przypomniał zarządzenia państwowe zabraniające sprawowania sakramentów i sporządzania ich dokumentacji dla wiernych spoza swojej grupy wyznaniowej przez duszpasterzy innych obrządków lub „sługi innego Kościoła". Naruszenie tego wymogu powodowało nieważność czynności na forum prawa państwowego ${ }^{22}$.

Przy tej okazji omówił szereg zarządzeń państwowych odnoszących się do sakramentu chrztu, w tym nakazujące katolickim rodzicom chrzcić swoje legalne potomstwo: „dziecię ma iść za rodzicami w religii katolickiej a tym samym chrzest

${ }^{19}$ H. Wyczawski, Przygotowania do studiów w archiwach kościelnych, Kalwaria Zebrzydowska 1989, s. 278.

${ }^{20}$ Jougan, Kancelaria parafialna, s. 47.

${ }^{21}$ Tamże, s. 49.

${ }^{22}$ A. Jougan przytacza fragment ustawy z 25 maja 1868 r.: „Przełożeni, słudzy lub członkowie Kościoła albo stowarzyszenia religijnego winni się wstrzymać od pełnienia funkcji służby Bożej wobec przynależnych do innego Kościoła lub stowarzyszenia religijnego, o które ich uprawnione osoby nie prosiły. Wyjątek może zajść tylko w tych poszczególnych wypadkach, w których właściwi duszpasterze albo słudzy innego Kościoła albo stowarzyszenia religijnego proszą o spełnienie należącego do nich aktu, albo gdy statuty lub przepisy spełnienie tego aktu dopuszczają. Oprócz tych wypadków uważa się akt taki jako bezskuteczny a władze winne na żądanie dotkniętej tym osoby prywatnej lub stowarzyszenia religijnego zaradzić temu w odpowiedni sposób".Tamże, s. 130-131. 
i wpis w księgę ochrzczonych jest obowiązkowy". Niewykazanie faktu udzielenia chrztu w postaci odpowiedniego wpisu do liber baptisatorum było naruszeniem przepisów państwowych: „Przez zatajenie doniesienia o chrzcie dziecka rodzice utrudniają także wykonanie dokładne przepisów państwowych, jak np. statystycznych wykazów młodzieńców obowiązanych do wojska”. Podobnie ,wzbranianie się ojca katolickiego aby jego dziecię było ochrzczone, uważa się z reguły za nadużycie władzy rodzicielskiej”. Jeśli dochodziło do takiej sytuacji, to krewni mogli domagać się przed sądem świeckim nakazania ojcu dopełnienia obowiązku chrztu dziecka ${ }^{23}$.

Dokonanie wpisu do księgi ochrzczonych wiązało się z koniecznością potwierdzenia stanu cywilnego rodziców: „W praktyce przyjąć trzeba tę normę zasadniczą, że wszelkie wpisy metrykalne, a zwłaszcza urodzony ochrzczonych, powinno się dokonywać tylko na podstawie dokumentów wiarogodnych, a więc głównie świadectwa ślubu rodziców". Oświadczenie ustne rodziców lub akuszerki nie było wystarczające dla ustalenia legalności potomstwa, a „fałszywe lub błędne zeznania stron przy wpisach metrykalnych władze rządowe zwykły przypisywać nie za winę stronom, ale za przeoczenie lub niedopilnowanie czynności urzędowej prowadzącym metryki" 24 .

Informację o udzieleniu chrztu należało wpisać bezpośrednio do księgi metrykalnej. Niedozwolone było posługiwanie się wcześniej sporządzonymi brudnopisami:

tego domagają się przepisy rządowe, które brulionów wcale nie znają (...).

Wpisywanie urzędowe aktów urodzenia i chrztu odbywać się ma w samej księdze metrykalnej Baptisatorum (nie w brulionach) w formie tabelarycznej, wedle formularza i rubryk urzędowo przepisanych ${ }^{25}$.

Obowiązujący na początku XX wieku formularz księgi ochrzczonych składał się z 13 kolumn. Każdy wpis zawierał następujące informacje: numer kolejny aktu, nazwisko i funkcja szafarza sakramentu, w osobnych polach data urodzin i chrztu dziecka, miejsce urodzenia (adres), imiona dziecka, religię rodziców, płeć dziecka, pochodzenie z legalnego (lub nie) związku. Dalsze informacje dotyczyły rodziców i okoliczności zawarcia związku małżeńskiego, a także nazwiska chrzestnych i ich miejsce zamieszkania. Ostatnie pole zawierało miejsce na uwagi zarówno bieżące, jak i dokonywane w późniejszym czasie ${ }^{26}$.

Zestaw rubryk w formularzu wystarczał do odnotowania faktu narodzin i udzielenia chrztu w większości przypadków. W sytuacjach niestandardowych (małżeństwa mieszane, chrzest „podrzutków”, brak informacji o ojcu itp.) proboszcz był zobowiązany sporządzić dodatkowe dokumenty lub podjąć dodatkowe czynności wyjaśniające. Omówieniu tych sytuacji i zasadom ich odnotowywania w liber baptisatorum ks. A. Jougan poświęcił obszerne fragmenty publikacji. Dla przykładu, w małżeństwach mieszanych konieczne było sporządzenie oświadcze-

\footnotetext{
${ }^{23}$ Tamże, s. 132-133.

${ }^{24}$ Tamże, s. 135-136.

25 Tamże, s. 142.

${ }^{26}$ Tamże, s. 144.
} 
nia o katolickim wychowaniu dziecka podpisanego przez oboje rodziców. W wypadku ,podrzutków” proboszcz, we współpracy z władzami gminy, miał obowiązek podjęcia działań w celu ustalenia rodziców. Jeśli było to niemożliwe, zwykle wpisywano jako rodziców osoby, które podjęły się wychowania dziecka. Przy tej okazji proboszcz sporządzał odpowiednią adnotację w rubryce „uwagi”. W wypadku urodzenia dziecka przez wdowę w czasie do 10 miesięcy po śmierci męża jako ojca wpisywano zmarłego małżonka, urodzone później dziecko otrzymywało nazwisko panieńskie matki ${ }^{27}$.

Kościół zawsze pilnie strzegł wyznaniowego charakteru małżeństwa. Obowiązywało to także w państwie Habsburgów. Oświecenie i rewolucja francuska sprawiły jednak, że jak stwierdziła A. Piegzik, także w katolickiej Austrii w XIX wieku dokonała się częściowa sekularyzacja prawa małżeńskiego. Patentem cesarskim z 1 czerwca $1811 \mathrm{r}$. został ogłoszony austriacki kodeks cywilny (Allgemeines Bürgerliches Gesetzbuch), który z jednej strony uwzględniał wyznaniowy charakter małżeństwa, w różnych Kościołach i związkach wyznaniowych, z drugiej jednak w ograniczonym zakresie dopuszczał możliwość zawierania cywilnych związków małżeńskich i udzielania rozwodów ${ }^{28}$. Kodeks z 1811 r. rozwijał, zapoczątkowany jeszcze patentem Józefa II z 1783 r., świecki model małżeństwa jako umowy dwojga ludzi zawartej w określonej formie dla realizacji przewidzianych prawem celów (m.in. wspólnej pomocy i zrodzenia potomstwa). W $1908 \mathrm{r}$. F. Zoll podkreślał, że przepisy regulujące małżeństwo w prawie austriackim, mimo że wiele z nich miało swoje źródło w wewnętrznym prawie związków wyznaniowych, ostatecznie swoją moc obowiązywania czerpały z norm ustanowionych przez państwowego ustawodawcę ${ }^{29}$.

Po zawarciu przez Austrię konkordatu (1855) cesarz wydał w 1856 r. patent małżeński, który w stosunku do katolików zawiesił niektóre postanowienia kodeksu z 1811 r. i wzmocnił wpływ Kościoła na związki małżeńskie zawierane przez jego członków. Po wojnie z Prusami w 1866 r. przywrócono zawieszone po konkordacie przepisy prawa małżeńskiego i kompetencje sądów państwowych w sprawach małżeńskich (ustawa małżeńska z 25 maja 1868 r.) ${ }^{30}$.

Taki stan w zakresie prawa małżeńskiego obowiązywał w Austrii do upadku cesarstwa. Ks. A. Jougan omawiał go w swoim podręczniku i choć krytycznie oceniał postanowienia ustawy z $1868 \mathrm{r}^{31}$, to w rozdziale pod znamiennym tytułem

${ }^{27}$ Tamże, s. 154, 180, 196.

${ }^{28}$ A. Piegzik, Przeszkody matżeńskie w ustawodawstwie dzielnicowym II RP, ,Folia Iuridica Universitatis Vratislaviensis”, 5 (2016) nr 1, s. 36-37.

${ }^{29}$ A. Karabowicz, Matżeństwo cywilne z konieczności (Notzivilehe) w Galicji w latach 18681918, w: Prawo blisko człowieka. Z dziejów prawa rodzinnego i spadkowego, red. M. Mikuła, Kraków 2008, s. 60-61.

${ }^{30}$ Tamże, s. 61-62

31 „Lecz wnet z początkiem ery konstytucyjnej w Austrii wyłoniły się dążności do wyjęcia małżeństwa z pod władzy Kościoła, a nawet do zaprowadzenia ślubów cywilnych. - Dążności te znalazły częściowo swe urzeczywistnienie w ustawie, tzw. majowej, dnia 25 maja 1868 (...). Ustawa ta zeświecczyła częściowo małżeństwo, pozostawiła bowiem $\S 75$ przepisujący formę kościelną w dawnej mocy, a tylko w wyjątkowych, na uwzględnienie zasługujących wypadkach, uprawniła 
„Czy cywilne ustawy małżeńskie obowiązują proboszczów” jednoznacznie stwierdził, że proboszcz w razie niedopełnienia obowiązków wypływających z ustawy musiał się liczyć $\mathrm{z}$ sankcjami prawa państwowego ${ }^{32}$.

Zawarcie małżeństwa było poprzedzone licznymi czynnościami i procedurami kancelaryjnymi (zaręczyny, zapowiedzi), których proboszcz musiał dopełnić, zanim dopuścił do zawarcia małżeństwa i dokonał wpisu do księgi zaślubionych (liber copulatorum). Działania te miały zostać udokumentowane w formie protokołu, który wraz ze wszystkimi załącznikami należało pieczołowicie przechowywać $\mathrm{w}$ archiwum parafialnym.

Wymogi dotyczące prawidłowego wpisu w księdze zaślubionych zostały określone zarówno w przepisach państwowych, jak i kościelnych. Najstarszym rozporządzeniem państwowym w tym zakresie był patent cesarski z 8 lutego 1784 r., który w zasadniczej treści obowiązywał przez cały XIX wiek. Informowano w nim m.in., że celem sporządzania ksiąg zaślubionych jest „zachowanie trwałego dowodu zawartego małżeństwa", a odpowiednich zapisów w tym celu powinien dokonywać osobiście „przełożony parafii”, w „przeznaczoną umyślnie na ten cel książkę". Określone także zostały informacje, jakie powinien zawierać wpis w księdze zaślubionych ${ }^{33}$. Na przełomie XIX i XX wieku formularz liber copulatorum zawierał siedem głównych rubryk: numer kolejny, data zawarcia małżeństwa, informacje o małżonkach, lista świadków, szafarz i uwagi. Rubryki przeznaczone na informacje o narzeczonych były podzielone na cztery sekcje: imię i nazwisko, wyznanie, wiek i stan cywilny ${ }^{34}$. Przepisy kościelne dotyczące wpisu w księdze zaślubionych określone zostały najpełniej w dekrecie Ne temere Kongregacji Soboru z 2 sierpnia 1907 r. $^{35}$

formę cywilną, t. j. dopuściła i umożliwiła pod pewnymi warunkami zarówno katolikom jak innowiercom zawierać małżeństwo wobec władzy cywilnej, czyli wprowadziła tak zw. małżeństwo cywilne z konieczności”. Jougan, Kancelaria parafialna, s. 332-333.

${ }^{32}$ A. Jougan przytoczył dosłowne brzmienie odnośnych przepisów: „Postanowienia ustawy cywilnej: § 78. u. c. Jeżeli oblubieńcy nie składają świadectwa na piśmie o dokonaniu w należyty sposób ogłoszeń (zapowiedzi), albo jeżeli osoby wymienione w § 49-52 i 54 nie okazują zezwolenia wymaganego do zawarcia przez nich małżeństwa, tudzież jeżeli ci, których pełnoletność nie jest widoczna, nie składają metryki chrztu lub pisemnego świadectwa o ich pełnoletności, albo jeżeli jaka inna zachodzi przeszkoda do małżeństwa, w takich przypadkach nie wolno jest duchownemu pod ciężką karą dawać ślubu dopóty, dopóki oblubieńcy nie złożą potrzebnych świadectw i nie usuną wszelkich przeszkód. Ślub udzielony przez duszpasterza wbrew postanowieniom § 78. ma cechę przekroczenia policyjnego a do postępowania karnego w takim wypadku jest kompetentną władza polityczna".Tamże, s. 374.

33 „Przy wpisaniu wyrazić należy: imię i nazwisko, wiek, zamieszkanie, tudzież stan małżonków, z uwagą, czy już poprzednio zostawali lub nie w związkach małżeńskich, dalej imię i nazwisko, tudzież stan ich rodziców i świadków, niemniej dzień, w którym małżeństwo zawarte zostało, na koniec nazwisko duchownego, przed którym przyzwolenie uroczyście oświadczono. Prócz tego należy wymienić dokumenty, mocą których zachodzące przeszkody zostały usunięte". Tamże, s. 616.

${ }^{34}$ Tamże, s. 622.

${ }^{35} \mathrm{~J}$. Dohnalik, Forma kanoniczna zawarcia matżeństwa - spojrzenie historyczne i postulat reform, „Annales Canonici”, 14 (2018) z. 11, s. 189-190. 
Najbardziej rozbudowany był fragment wpisu z informacjami o zaślubionych. Zawierał nie tylko imiona i nazwiska, ale także adresy zamieszkania, a w wypadku wojskowych szczegółowy przydział wojskowy. W tej rubryce należało także podać informacje o rodzicach zaślubionych, w tym również czy i kiedy zmarli. Przy osobach adoptowanych należało podać zarówno nazwisko „ojca adoptującego, lub nazwisko rodowe matki adoptującej”, jak i poprzednie rodowe nazwisko adoptowanego ${ }^{36}$.

W rubryce ,uwagi” należało odnotować, jakie dokumenty wykorzystano w kancelaryjnej procedurze przygotowania do ślubu. Ich oryginały miały być złożone w archiwum parafialnym. Do najważniejszych należały świadectwa chrztu narzeczonych, poświadczenia adresów zamieszkania, świadectwa zapowiedzi i uzyskanych dyspens. Najwięcej dokumentów wymaganych było w wypadku, gdy pan młody był wojskowym. Należało wówczas uzyskać liczne zezwolenia władz wojskowych i państwowych ${ }^{37}$.

Po zawarciu związku małżeńskiego oryginałów dokumentów nie wolno było zwracać stronom ani nawet wypożyczać za pokwitowaniem, ponieważ „,dokumenty ślubne służą jako załączniki na dowód przestrzeganego postępowania prawnego przy zawieraniu małżeństw". Nawet władzom państwowym nie wolno było wydawać oryginałów bez zgody rządu krajowego we Lwowie. Pełną dokumentację związaną z zawarciem małżeństwa miał obowiązek przechowywać ,właściwy proboszcz nowożeńców, który daje ślub lub udziela delegacji”. Ten sam duchowny był zobowiązany do dokonania wpisu w księdze zaślubionych w podlegającej sobie parafii. W wypadku ślubów udzielanych na podstawie delegacji w innym miejscu tamtejszy proboszcz miał obowiązek przechowywać jedynie świadectwo otrzymanej delegacji ${ }^{38}$.

Do księgi zmarłych (liber mortuorum) proboszcz był zobowiązany wpisywać wszystkie przypadki z terenu parafii. Dotyczyło to również zmarłych niemieszkających na stałe na danym terenie. Poza przypadkami śmierci naturalnych należało wpisywać także inne zgony, np. martwo urodzonych dzieci, śmierci gwałtownej (wypadki czy samobójstwa) i skazańców. Rejestracja zgonów dotyczyła wszystkich zmarłych bez względu na to, czy udzielono im kościelnego pogrzebu, czy takiej ceremonii odmówiono.

Formularz księgi zmarłych został określony patentem cesarskim z $1781 \mathrm{r}$. i obejmował: dzienną datę zgonu, adres miejsca zgonu, imię i nazwisko zmarłego, wyznanie, płeć, wiek i przyczynę śmierci ${ }^{39}$. Dekret z 1784 r. pozwalał notować informacje o udzieleniu ostatniego namaszczenia. O możliwość dokonywania takiego wpisu zabiegały władze kościelne. Informacje na ten temat należało umieszczać w rubryce „uwagi”, nie wolno natomiast było przeznaczać na ten cel osobnej rubryki ani przesyłać tych informacji w wykazach do władz świeckich. Liber mortuorum w świetle ustawodawstwa józefińskiego miał mieć przede wszystkim charakter państwowy. Na przełomie XIX i XX wieku formularz tej

\footnotetext{
${ }^{36}$ Jougan, Kancelaria parafialna, s.625-626.

${ }^{37}$ Tamże, s. 630-632.

${ }^{38}$ Tamże, s. 633.

${ }^{39}$ Rachwał, Księgi metrykalne z czasów zaboru, s. 313-314.
} 
księgi liczył dziesięć kolumn. Dodana została informacja z nazwiskiem szafarza pogrzebu kościelnego, jeśli taki miał miejsce. W razie jego braku rubrykę pozostawiano pustą $^{40}$.

W przypadku przeprowadzenia ekshumacji w „uwagach” należało podać jej datę i powód. Informacje o śmierci wojskowych w służbie czynnej należało odnotowywać w metrykach wojskowych. Zarządzenie władz państwowych z $1869 \mathrm{r}$. zabraniało umieszczania informacji o ewentualnym związku cywilnym zmarłych. Mimo państwowego charakteru liber mortuorum ks. A. Jougan zalecał jednak, aby w „uwagach” odnotowywać informacje ważne ze względów kościelnych, jak np. odmowa udzielenia kościelnego pogrzebu wraz z podaniem powodu. Jeśli przy pogrzebie samobójcy dopuszczono obrzęd kościelny, również należało podać powód. Najczęściej było to lekarskie orzeczenie o niepoczytalności w chwili samobójstwa ${ }^{41}$.

\section{Inne formy dokumentacji parafialnej}

Poza księgami metrykalnymi w kancelariach parafialnych powstawały na przestrzeni XIX wieku liczne dodatkowe księgi, które miały usprawnić funkcjonowanie urzędu parafialnego. Początkowo ich treść i formy prowadzenia były zróżnicowane i uzależnione od praktyki danej kancelarii. Z czasem poszczególni biskupi nakazywali w swoich diecezjach prowadzenie konkretnych ksiąg parafialnych, a nawet określali ich formularze. Najobszerniejszy wykaz takich ksiąg parafialnych, liczący 27 pozycji, zawierała instrukcja wizytacji dziekańskich dla archidiecezji lwowskiej obrządku łacińskiego z $1896 \mathrm{r}^{42}$ Waga informacji gromadzonych w poszczególnych księgach była różna i zapewne były parafie, w których nie prowadzono ich kompletu. Mimo nazywania większości dokumentacji parafialnej z tej grupy „księgami” z czasem forma ich prowadzenia ulegała zmianie. Powoli rozwijała się technika gromadzenia luźnej dokumentacji dotyczącej danej kwestii w teczkach (akta spraw) i pojawiały się kartoteki ${ }^{43}$.

Za najważniejszą uznawano dokumentację związaną z prowadzeniem ksiąg metrykalnych. Taki charakter miała m.in. księga zapowiedzi (liber bannorum). Jej formularz liczył 13 rubryk, z których pierwsza zawierała numer kolejnych zapowiedzi głoszonych w danej parafii. Osiem rubryk zawierało informacje dotyczące narzeczonych: imiona i nazwiska narzeczonych i ich rodziców, wykonywany zawód, wiek, stan cywilny, wyznanie, miejsce zamieszkania zawierające zarówno adres, jak i nazwę parafii. Trzy rubryki zawierały informacje dotyczące wygłoszenia zapowiedzi, ich daty i rangę święta kościelnego (niedziela lub inne święto). Ostatnia rubryka „uwagi” była przeznaczona na późniejsze adnotacje, takie jak data i miejsce zawarcia ślubu czy miejsce, w którym zamieszkali nowożeńcy. Szczegółowe przepisy państwowe nakazywały, aby nie tylko w księdze zapowiedzi, ale także podczas ich wygłaszania podawać dokładnie stan cywilny narzeczo-

\footnotetext{
${ }^{40}$ Jougan, Kancelaria parafialna, s. 703, 706.

${ }^{41}$ Tamże, s. 704-705.

${ }^{42}$ Tamże, s. 853.

${ }^{43} \mathrm{Kufel}$, Kancelaria, registratura i archiwum parafialne, s. 50.
} 
nych (np. panna, wdowiec), a w odniesieniu do osób adoptowanych w dzieciństwie obok nazwiska przybranego ojca podawać także nazwisko rodowe matki i poprzednie nazwisko rodowe adoptowanego ${ }^{44}$.

Na podstawie zarządzenia konsystorza lwowskiego proboszczowie zostali zobowiązani do prowadzenia innych ksiąg parafialnych i wykazów związanych ze sprawowaniem sakramentu małżeństwa - wśród nich tzw. liber denegatarum copulationum. Księga ta zawierała informacje na temat osób, którym ślubu kościelnego odmówiono, wraz z podaniem powodu kanonicznego. Niektóre przeszkody do zawarcia małżeństwa występujące w prawie kościelnym nie obowiązywały w przypadku zawarcia związku cywilnego ${ }^{45}$. W osobnych spisach gromadzono informacje o małżeństwach, które otrzymały zgodę sądu świeckiego na separację ${ }^{46}$, a tzw. „prywatny liber copulatorum” był rejestrem małżeństw zawartych na łożu śmierci lub bez obecności duchownego na podstawie procedury określonej w dekrecie Ne temere, których to związków nie można było zapisać w urzędowym liber copulatorum. Inny charakter nosił tzw. „Spis matek nieślubnych”, zawierający prawdziwe nazwiska matek podrzutków, jeśli udało się to ustalić proboszczowi. Tę grupę ksiąg konsystorz lwowski zaliczał do kategorii ksiąg poufnych, których nawet nie należało przechowywać w kancelarii parafialnej, ale w oddzielonym od niej archiwum parafialnym ${ }^{47}$. Zawierały one informacje ważne ze względów religijnych i kościelnych, a których nie wolno było umieszczać w oficjalnych księgach metrykalnych.

Kolejna grupa ksiąg parafialnych służyła rejestrowaniu wybranych wydarzeń z życia religijnego wiernych i czynności duszpasterskich. Najważniejsza z nich była księga odwiedzin chorych (liber visitationis infirmorum). Jej standardowy formularz liczył osiem kolumn. Gromadzone informacje były rejestrowane w ramach kolejnych lat i obejmowały: numer kolejny odwiedzin w ramach roku, datę dzienną wizyty, adres, imię i nazwisko chorego. Rubryka „provisus” dzieliła się na cztery kolumny z nagłówkami oznaczającymi rodzaj udzielonej posługi: spowiedź, komunia św., ostatnie namaszczenie, absolucja generalna. Szafarz zaznaczał udzielone posługi najczęściej ukośną kreską stawianą w odpowiednich miejscach. Dwie ostatnie kolumny obejmowały informacje o ewentualnym czasie i przyczynie zgonu. Ważną księgą w tej grupie był rejestr bierzmowanych (liber conformatorum). Jego formularz zawierał numer kolejny i datę dzienną, imię i nazwisko oraz wiek bierzmowanego, nazwisko szafarza i miejsce udzielenia sakramentu. Warto zwrócić uwagę, że w tej księdze nie odnotowywano adresów bierzmowanych ${ }^{48}$.

$\mathrm{Z}$ kolei celem księgi status animarum (liber status animarum), jak pisze ks. A. Jougan, było ukazanie

stanu parafii pod względem statystyki duszpasterskiej, a tym samym imienne, i liczebne zestawienie wszystkich parafian wedle całych rodzin z uwydatnie-

\footnotetext{
${ }^{44}$ Jougan, Kancelaria parafialna, s. 392.

${ }^{45}$ Karabowicz, Matżeństwo cywilne z konieczności (Notzivilehe) w Galicji, s. 63.

${ }^{46}$ Jougan, Kancelaria parafialna, s. 202.

${ }^{47}$ Tamże, s. 862, 868.

${ }^{48}$ Tamże, s. 854.
} 
niem zmian, jakie u nich zaszły z biegiem czasu, bądź pod względem przyrostu

(ślubów i urodzin), bądź ubytku (przez zgony).

Status animarium miał być niejako streszczeniem zapisów rozproszonych w księgach metrykalnych i innej dokumentacji, aby ukazać w jednym miejscu dynamikę zmian zachodzących w parafii. Należyte prowadzenie tej księgi miało pomóc w organizacji pracy duszpasterskiej i działalności kancelarii, np. przy sporządzaniu sprawozdań dla władz świeckich i kościelnych. Uzupełnianie liber status animarum zalecano szczególnie w czasie kolędy. W poszczególnych parafiach były praktykowane różne sposoby prowadzenia tej księgi - najczęściej według nazwisk mieszkańców lub kolejności domów w poszczególnych wsiach. Sprawne poruszanie się po tak sporządzanym zbiorze informacji wymagało licznych indeksów. Najważniejszym z nich był indeks osobowy. Formularz tej księgi, zalecany przez ks. A. Jougana, liczył osiem kolumn. W pierwszej podany był numer domu w danej wiosce, w następnej wykaz domowników z określeniem pokrewieństwa i powinowactwa (żona, dzieci, teściowie). Wpisy w dalszych kolumnach dotyczyły wyznania i obrządku, daty urodzin, ślubu, zgonu i bierzmowania. Ostatnia poświęcona była na uwagi. Autor odnotował fakt, że w większych miastach rejestr status animarum coraz częściej był prowadzony w postaci kartoteki. Nie poświęcił jednak więcej uwagi tej formie dokumentacji ${ }^{49}$.

Osobną grupę stanowiły rejestry związane z nauczaniem parafialnym. Należały do niej księga wyjazdów (liber excursionum) i księga wygłaszanych w kościele parafialnym kazań i nauk (liber catechesium et concionum). One również miały postać formularzy. Do pierwszej proboszcz wpisywał daty wyjazdów do wiosek na terenie parafii w celu przeprowadzania nauki katechizmu dla dzieci, młodzieży i dorosłych. Nauczanie odbywało się okazjonalnie i nie miało związku z katechezą szkolną. Z reguły było przeprowadzane w wioskach najbardziej oddalonych od kościoła parafialnego, skąd wierni rzadziej uczestniczyli w nabożeństwach parafialnych, i miało charakter uzupełniający wiedzę religijną mieszkańców oraz służyło podtrzymywaniu kontaktu proboszcza z wiernymi. Druga z tych ksiąg zawierała tematy kazań i innych nauk, w tym katechizmowych, wygłaszanych w kościele parafialnym z podaniem daty i rangi święta kościelnego, z którym były połączone ${ }^{50}$.

Tradycyjnie dużym szacunkiem cieszyła się kronika parafialna (liber memorabilium). Podkreślając jej znaczenie, ks. A. Jougan nawiązywał do tradycji średniowiecznych kronik klasztornych, a nawet przekonywał, że ,dawniej w polskich parafiach kroniki spisywano bardzo starannie”. Zalecał, aby przy ich sporządzaniu ,kierując się taktem, roztropnością i zdrowym sądem ocenić z góry jakie zapiski zdołają w potomności przynieść pożytek następcom w parafii i ogółowi”. Przestrzegał przed stronniczością, a kronika miała stać się ,,indeksem i kluczem do dziejów parafii". Z tego względu zalecał opisywanie w kronice dziejów parafii, kaplic, plebanii, kopiowanie dokumentów potwierdzających nadania i stan majątku kościelnego, w tym pozyskiwanych nowych funduszy. W kronice powin-

\footnotetext{
${ }^{49}$ Tamże, s. 857.

${ }^{50}$ Tamże, s. 860-862.
} 
ny się znajdować opisy wydarzeń zarówno kościelnych, jak i świeckich ${ }^{51}$. Wydaje się, że jego oczekiwania w stosunku do zawartości kroniki były bardzo rozbudowane, co groziło powielaniem informacji gromadzonych w innych księgach i rejestrach kościelnych.

Liber ordinationum wywodzi się z tradycji rejestrowania docierających do parafii drogą obiegową zarządzeń biskupa i konsystorza. Do obowiązków proboszcza należało przepisać je do odrębnej księgi w celu zachowania takiego odpisu w parafii. W XIX wieku coraz częściej zarządzenia biskupów drukowane były w periodykach diecezjalnych dla duchowieństwa ${ }^{52}$. W związku z tym obowiązki proboszcza w tym zakresie uległy uproszczeniu, gdyż był on zobowiązany napływające czasopisma ,starannie zbierać i gromadzić ich roczniki, oprawiać, aby w każdej parafii znajdował się ich komplet”. Jednak w gąszczu przepisów i innych treści znajdujących się w rocznikach pism diecezjalnych nie było łatwo odszukać potrzebne zarządzenie, dlatego zalecano prowadzenie tzw. liber normalium. Był to tabelaryczny spis zarządzeń w porządku chronologicznym zawierający informację o temacie rozporządzenia, jego streszczenie oraz odsyłacz do drukowanego wydania ${ }^{53}$.

Księga fundacji mszalnych (liber missarum fundatarum) zawierała wykaz mszy św., które miały być odprawione w intencjach wyznaczonych przez fundatorów. Było to długotrwałe zobowiązanie dotyczące kolejnych proboszczów danej parafii. W zamian za dochody z ulokowanych na długi termin środków, byli oni zobligowani do odprawiania mszy św. w konkretnych intencjach, w określonym terminie, liczbie i z wyznaczoną oprawą liturgiczną ${ }^{54}$. Ze względu na długotrwały charakter tych zobowiązań podlegały one szczególnemu nadzorowi ordynariusza, a także państwa, które nakładało na tego typu fundacje odpowiednie podatki. Dlatego opis fundacji zawarty w księdze na podstawie sporządzonej umowy fundacyjnej musiał wyszczególniać wszystkie zobowiązania strony kościelnej i płynące z fundacji dochody. Wpisy w księdze były nie tylko formą kontroli realizacji zobowiązań fundacyjnych. $Z$ upływem czasu siła nabywcza dochodów czerpanych przez plebanów z zapisów zmniejszała się, dlatego domagali się oni od konsystorza redukcji zobowiązań. Taka decyzja wymagała jednak postępowania przewidzianego przez przepisy kościelne i państwowe. Umowy fundacyjne oraz wpisy w omawianej księdze były podstawą roszczeń w tym zakresie tak strony kościelnej, jak i potomków fundatorów ${ }^{55}$.

Podobny charakter, tyle że dokumentujący bieżące zobowiązania stypendialne duchowieństwa, miała księga intencji mszalnych (liber stipendiorum manualium), która zawierała spis bieżących intencji mszalnych w parafii. Prawidłowy

${ }^{51}$ Tamże, s. 858-860.

${ }^{52}$ Kufel, Kancelaria, registratura i archiwum parafialne, s. 52-53.

${ }^{53}$ Tamże, s. 857-858.

${ }^{54}$ B. Walicki, Fundacja mszalna pamięci ks. Stanisława Nyrkowskiego, „Rocznik Kolbuszowski”, 13 (2013) s. 103-105.

${ }^{55}$ Jougan, Kancelaria parafialna, s. 863-865. 
wpis w niej powinien zawierać informację, kto zamówił mszę, w jakiej intencji, jakie stypendium zostało przyjęte przez duchownego i kiedy msza została odprawiona.

Bieżące dochody i wydatki parafii notowane były w tzw. liber rationum ecclesiae. Rejestrowano w niej dochody z majątku ruchomego i nieruchomego parafii, $\mathrm{w}$ tym ofiar wiernych składanych z racji nabożeństw. Pełny wykaz źródeł tych dochodów miał być umieszczony na początku lub końcu księgi. Na podstawie zapisów w tej księdze należało po zakończeniu roku kalendarzowego zrobić roczne zestawienie dochodów i wydatków parafii. Osobiste dochody duchownych $\mathrm{z}$ tytułu iura stolae notowane były $\mathrm{w}$ osobnej księdze liber proventus ex iurae stolae. Księgi dotyczące spraw finansowych podlegały kontroli władzy kościelnej i państwowej ${ }^{56}$.

\section{Pisma urzędowe i styl kancelaryjny}

Kancelaria parafialna w Austrii prowadziła rozbudowaną korespondencję z władzami kościelnymi i świeckimi różnych szczebli, organizacjami i osobami prywatnymi. A. Jougan w swoim podręczniku wiele uwagi poświęcił temu obszarowi działalności duchowieństwa parafialnego, w tym specyficznemu kościelnemu stylowi kancelaryjnemu, jak go nazywał - ,stylowi duchownemu”, do którego reguł winni się stosować proboszczowie przy sporządzaniu korespondencji urzędowej. Zasady tego stylu dzielił na wewnętrzne i zewnętrzne. Do wewnętrznych zaliczał przede wszystkim konieczność podawania prawdziwych informacji, unikanie „stronniczego zabarwienia, a nawet umyślnego przemilczenia całej prawdy, nie mówiąc już o tym, że nie godzi się wprost fałszywie sprawę jakąś przedstawić”. Zwięzłość i jasność narracji, prostotę i precyzję języka zaliczał również do form wewnętrznych. Przestrzeganie ich miało służyć zachowaniu godności i powagi duchownego oraz sprawowanego urzędu ${ }^{57}$.

Przestrzeganie zewnętrznych form prowadzenia korespondencji urzędowej służyło „utrzymaniu porządku kancelaryjnego”. Każde pismo należało przygotowywać najpierw w postaci dokładnego konceptu, który był podstawą sporządzenia czystopisu. Koncept miał być przechowywany w ,aktach registratury” jako potwierdzenie wysłanej korespondencji. O ile brudnopisy można było sporządzać na dowolnym papierze, o tyle ekspediowane pisma, w zależności od wagi sprawy i rangi odbiorcy, należało spisywać na papierze odpowiedniej jakości. Czystopisy winny być sporządzane na całym arkuszu papieru, a forma półarkusza była dopuszczalna jedynie do poświadczeń i pokwitowań. W kancelarii parafialnej obo-

${ }^{56}$ Tamże, s. 866-867.

${ }^{57}$ „Godność kapłańska musi się objawiać także w pisemnej korespondencji, zwłaszcza urzędowej. Należy z niej przeto wykluczyć wszelkie wyrazy i zwroty prostackie, żartobliwe lub sarkastyczne. Kto otrzymał rozkaz, z którym trudno mu się pogodzić, wolno mu czynić przedstawienia, lecz unikać trzeba przy tym zwrotów obrażających. Wobec władzy przełożonej wypada sąd własny podawać tylko jako osobiste mniemanie, a nie jako przekonanie niewzruszone. Kto jest zmuszony do skarg na drugich lub do bronienia się przed zarzutami, powinien pamiętać, że posługiwanie się posądzaniem gołosłownym lub obelgami przemawia raczej na jego własną niekorzyść". Tamże, s. 870 . 
wiązywał pewien stały schemat rozmieszczania elementów formalnych i merytorycznych sporządzanego pisma:

Napis naczelny czyli inwokacja władzy, do której się pismo odnosi pisze się w pewnym odstępie od góry poprzez całą stronicę arkuszową, niżej od inwokacji, zwykle po prawej stronie nieco wyżej od samej korespondencji, kładzie się urząd, miejsce i datę, po lewej na poziomie z samą korespondencją daje się rubrum czyli streszczenie jak najkrótsze sprawy: proboszcz N. N. prosi o urlop, składa sprawozdanie $\mathrm{z}$ nauki religii itp. ${ }^{58}$.

Jeżeli pismo zawierało załączniki (alegata), należało wyraźnie zaznaczyć w treści, czy mają one pozostać u odbiorcy, czy należy zwrócić je do kancelarii nadawcy. Zalecano posługiwanie się jako załącznikami uwierzytelnionymi odpisami, aby oryginały dokumentów nie opuszczały kancelarii. W przypadku wielu różnych załączników należało je łączyć „klamerką blaszaną lub nicią”, a w treści pisma „podać ich numerowany wykaz”. Podstawową formą zabezpieczania korespondencji było używanie odpowiednich kopert, które powinny być ,przy posyłce ważnych dokumentów opieczętowane i polecone". Odradzano natomiast przesyłanie pism bez koperty, nawet jeśli miałyby one być odpowiednio złożone i zapieczętowane, gdyż taka forma nie gwarantowała zachowania tajemnicy korespondencji $i^{59}$.

Wiele uwagi ks. A. Jougan poświęcił omówieniu typologii wysyłanych pism. Do najważniejszych zaliczał: listy, sprawozdania, prośby, podania, skargi, rekursy, protokoły, kopie i duplikaty. Każdy rodzaj pisma został w podręczniku krótko scharakteryzowany z uwzględnieniem informacji, do jakich spraw się odnosi, jakie są specyficzne formy jego stylu i stosowanej terminologii ${ }^{60}$.

Najwięcej uwagi poświęcił zasadom sporządzania pism do konsystorza. Było to $\mathrm{w}$ zasadzie przypomnienie zaleceń konsystorza lwowskiego $\mathrm{w}$ tej sprawie z 1886 r. Należało używać papieru o wymiarach $34 \times 21 \mathrm{~cm}$. Na odwrocie arkusza zawierającego podanie powinno się zamieścić tzw. rubrum, czyli regest: kto jest autorem, do kogo kierowana jest sprawa i czego dotyczy. Konsystorz zalecał także, aby w jednym piśmie kierowanym do władzy diecezjalnej omawiać tylko jedną sprawę. Regest wraz z przestrzeganiem zasady ,jedno pismo jedna sprawa" ułatwiały dekretację wpływającej korespondencji ${ }^{61}$.

Jeżeli sprawa poruszana przez proboszcza nawiązywała do wcześniejszej korespondencji z władzą diecezjalną, należało powołać się na te wcześniejsze pisma w tekście, z uwzględnieniem ich numeracji nadanej przy ekspedycji z kancelarii konsystorskiej. Informacje te powinno się także powtórzyć w zewnętrznym rege-

${ }^{58}$ Tamże, s. 871.

${ }^{59}$ Tamże, s. 872.

${ }^{60}$ Tamże, s. 872-875.

${ }^{61}$ „W jednym podaniu nie należy załatwiać kilku, spraw, bo to uniemożliwia rozdzielenie spraw pomiędzy poszczególnych referentów i opóźnia załatwienie sprawy, gdyż jeden referent musi czekać na drugiego. Z tych względów należy sprawy, chociażby pokrewne, każdą, osobno przedkładać. Można wszelako kilka spraw w osobnych podaniach przedstawionych, przesyłać w jednej kopercie, ale tylko do Konsystorza; do władz państwowych łączyć w jednej kopercie kilku spraw nie można, bo im to utrudnia manipulację kancelaryjną i powoduje przewlekanie się sprawy”.Tamże, s. 876. 
strze. Ułatwiało to urzędnikom odszukanie priorów w konsystorzu. Nie należało natomiast załączać oryginałów pism, na które się proboszcz powoływał ${ }^{62}$. W korespondencji z konsystorzem obowiązywała droga służbowa. $Z$ wyjątkiem spraw nagłych, takich jak prośby o dyspensy i związanych z tajemnicą spowiedzi, należało kierować ją za pośrednictwem urzędu dziekańskiego ${ }^{63}$.

W ramach swoich obowiązków parafie kontaktowały się także z urzędami państwowymi różnych szczebli (np. starostwami czy ministerstwami). Państwowe władze austriackie często przypominały o autonomicznym statusie urzędów kościelnych względem administracji państwowej:

stosunek między starostwami a urzędami dziekańskimi i parafialnymi nie jest ani współrzędny ani podrzędny, a przeto w stosunkach wzajemnych urzędowych winny oba te urzędy zachowywać formy grzeczności, jakie się zwykle praktykują między osobami od siebie niezależnymi.

Z tego względu władze rządowe zwracały uwagę wszystkim szczeblom administracji państwowej, aby w korespondencji z urzędami kościelnymi unikać formy poleceń i zarządzeń, a stosować formę zawiadomienia lub odezwy. W tytulaturze duchownych polecano zachowywać formy grzecznościowe „wielebny”, „przewielebny”, a prośby o udzielenie odpowiedzi przez księdza należało poprzedzać zwrotami „zechce”, „raczy”. Na zasadzie wzajemności konsystorz lwowski nakazywał księżom w korespondencji z władzami świeckimi stosowanie się do oficjalnych tytułów oraz nazw urzędów i urzędników, a także przestrzeganie ogólnych form grzecznościowych ${ }^{64}$.

Według zaleceń konsystorza językiem korespondencji wewnątrz struktur kościelnych „między duchownymi obrządków rzymsko-katolickiego i grecko-katolickiego" winna być łacina. W kontaktach z władzami świeckimi obowiązywała większa różnorodność wynikająca z równouprawnienia języków poddanych cesarza: „rząd przyznawszy prawo obywatelstwa wszystkim językom w państwie, pozostawił duchowieństwu wszelką swobodę co do wyboru języka urzędowego z wyjątkiem wpisów i świadectw metrykalnych". Dla ułatwienia kontaktów urzędowych ks. A. Jougan zalecał, aby w kontaktach z władzami świeckimi w Galicji używać języka polskiego, a w korespondencji z władzami wojskowymi i wszystkimi urzędami państwowymi poza Galicją języka niemieckiego.

Niewiele uwagi poświęcił ks. A. Jougan kwestiom związanym z uwierzytelnianiem dokumentów powstających w kancelarii parafialnej. W rozdziale o wystawianiu świadectw i zaświadczeń autor zalecał, aby na dokumentach obok podpisu plebana wyciskać pieczęć parafialną: „Powinna ona być czysta, o tyle przynajmniej, aby znajdujący się na niej w okolu napis, względnie wyryte na niej w środku godło (postać) odbiło się na pieczęci czytelnie i wyraźnie”. Odra-

${ }^{62}$ „Samej odezwy, na którą się trzeba powołać, nie przyłącza się do sprawozdania jako alegat, gdyż ona powinna pozostać w aktach kancelaryjnych w registraturze, a zresztą jej koncept znajduje się w kancelarii tej władzy, która ją wydała". Tamże, s. 877.

${ }^{63}$ Tamże, s. 878.

${ }^{64}$ Tamże, s. 879. 
dzał stosowanie pieczęci opłatkowych i lakowych jako „kruchych i łamliwych”, a zalecał stosowanie ,płynu barwnego (tynktury) dla pieczęci w kauczuku lub metalu" 65 .

\section{Podsumowanie}

Kancelarie parafialne w monarchii habsburskiej były ważnymi instytucjami zarówno w administracji kościelnej, jak i państwowej. Z tego względu ich organizacja, kompetencje i prowadzona dokumentacja były regulowane przepisami państwowymi i kościelnymi. Katolicka monarchia korzystała z możliwości, jakie w dziedzinie nadzoru nad ważnymi obszarami życia społecznego dawały struktury kościelne. Postępujące procesy przemian społeczeństwa, w tym o charakterze laicyzacyjnym, powodowały konieczność zmian w wielu obszarach administrowania państwem, w tym również w zakresie spraw obsługiwanych przez kancelarie parafialne. Na tym tle dochodziło niekiedy do konkurencji przepisów i procedur kościelnych i państwowych. Państwo katolickie starało się uwzględniać stanowisko eklezjalne w konfliktowych materiach, ale ostatecznie kierowało się racją stanu, wydając przepisy dotyczące np. zasad prowadzenia ksiąg metrykalnych jako rejestrów państwowych czy działalności kancelarii parafialnych w zakresie zadań wyznaczanych im przez państwo. W takich sytuacjach władze kościelne uznawały interesy państwa, a jeśli było to konieczne, nakazywały plebanom prowadzenie dodatkowych rejestrów, gromadzących informacje, które nie mogły być odnotowywane w księgach mających status publiczny, a ważnych ze względów religijnych. Zależność od dwóch ośrodków dyspozycyjnych, mimo potencjalnych konfliktów, pozytywnie wpływała na wzrost profesjonalizacji kancelarii parafialnych i szacunek dla obu porządków prawnych ze strony duchowieństwa parafialnego. Analiza zaleceń zawartych w podręczniku ks. A. Jougana ukazuje postulowany wysoki poziom organizacji kancelarii parafialnych w biurowej obsłudze zadań wypływających z kościelnych i świeckich zarządzeń. Czy i w jakim zakresie w poszczególnych parafiach udawało się realizowanie tych wymagań na odpowiednim poziomie, pozostaje otwartym problemem badawczym.

${ }^{65}$ Tamże, s. 93. 


\section{REFERENCES / BIBLIOGRAFIA}

\section{Źródla}

Jougan Alojzy, Kancelaria parafialna czyli zbiór przepisów kościelnych i państwowych dla urzędów parafialnych, ze szczególnym uwzględnieniem ksiąg metrykalnych, Lwów 1912.

\section{Opracowania}

Dohnalik Jan, Forma kanoniczna zawarcia matżeństwa - spojrzenie historyczne i postulat reform, „Annales Canonici”, 14 (2018) z. 11, s. 183-202.

Gawrysiakowa Janina, Grupy wyznaniowe ludności w Lubelskiem w XIX wieku, Lublin 1992.

Karabowicz Anna, Małzeństwo cywilne z konieczności (Notzivilehe) w Galicji w latach 1868-1918, w: Prawo blisko człowieka. Z dziejów prawa rodzinnego i spadkowego, red. M. Mikuła, Kraków 2008, s. 59-70.

Krętosz Józef, Józefiński proces budowy Kościoła państwowego na terenie monarchii habsburskiej w okresie rząów cesarza Józefa II (1780-1790), „Śląskie Studia Historyczno-Teologiczne", 29 (1996) s. 41-67.

Kufel Robert, Kancelaria, registratura i archiwum parafialne na ziemiach polskich od XII do początków XXI wieku, Zielona Góra 2011.

Kumor Bolesław, Metryki parafialne $w$ archiwach diecezjalnych, „Kwartalnik Historii Kultury Materialnej”, (1966) nr 14, z. 1, s. 65-75.

Kumor Bolesław, Przepisy państwowe i kościelne dotyczace metryk kościelnych w zaborze austriackim (1800-1914), „Przeszłość Demograficzna Polski”, 7 (1975) s. 93-107.

Moskal Tomasz, Historia ksiag metrykalnych kościoła katolickiego na ziemiach polskich, „Archiwariusz. Biuletyn Archiwum Archidiecezjalnego w Poznaniu”, (2005) nr 1, s. 55-82.

Piegzik Aleksandra, Przeszkody matżeńskie w ustawodawstwie dzielnicowym II RP, „Folia Iuridica Universitatis Vratislaviensis", 5 (2016) nr 1, s. 25-50.

Rachwał Piotr, Księi metrykalne z czasów zaboru austriackiego $w$ archiwach parafialnych $w$ Lubelskiem - regulacje prawne, stan zachowania, „Rocznik Lubelskiego Towarzystwa Genealogicznego", 6 (2015) s. 306-325.

Rachwał Piotr, Ruch naturalny ludności rzymskokatolickiej w Lubelskiem w świetle rejestracji metrykalnej z lat 1582-1900, Lublin 2019.

Walicki Bartosz, Fundacja mszalna pamięci ks. Stanisława Nyrkowskiego, ,Rocznik Kolbuszowski", 13 (2013) s. 103-114.

Wyczawski Hieronim, Przygotowania do studiów w archiwach kościelnych, Kalwaria Zebrzydowska 1989. 


\title{
THE PARISH OFFICE IN THE AUSTRIAN PARTITION AND ITS DOCUMENTATION AT THE TURN OF THE 19TH AND 20TH CENTURIES
}

\begin{abstract}
The Catholic Church fulfilled important tasks in the administrative structure of the Habsburg monarchy. They were carried out basing on the parish network as well as state and church regulations. For their fulfilment, an efficient parish office was necessary, which, using appropriate forms, registered various information about the pastoral activity and life of the congregation. The article presents the principles of the organization of offices, registry and archives in Catholic parishes of the Austrian partition at the peak of their development at the turn of the 19th and 20th centuries. The goals and methods of keeping vital records books and other forms of parish documentation as well as the rules of official correspondence were discussed. The basis for the study was the manual for running a parish office for the clergy, written by Rev. Alojzy Jougan, a professor at the University of Lviv in 1912, in which the formal, legal and practical-pastoral principles of running a parish office were discussed.
\end{abstract}

Keywords: parish office; parish archive; parish books; Church in the Austrian partition 